\title{
The Global Economy During COVID-19: A Study on Increasing Disparity
}

\author{
Mohammad Ariful Islam ${ }^{1} \&$ Syed Masrur Tehzib ${ }^{2}$ \\ ${ }^{1}$ Assistant Professor, Department of Banking and Insurance, Faculty of Business Studies, University of Dhaka, \\ Shahbag, Bangladesh \\ ${ }^{2}$ Independent Researcher, Harvard Summer School, Harvard University, USA \\ Correspondence: Mohammad Ariful Islam, Assistant Professor, Department of Banking and Insurance, Faculty \\ of Business Studies, University of Dhaka, Shahbag, Dhaka, Bangladesh. E-mail: mail2md.arif@gmail.com
}

Received: September 30, 2021

Accepted: December 25, 2021

Online Published: January 14, 2022

doi:10.5539/ijbm.v17n2p68

URL: https://doi.org/10.5539/ijbm.v17n2p68

\begin{abstract}
COVID-19 has become an ongoing issue in the present business world. The topic raises confusion and debate over many resolved issues. Not only the developing but also developed countries faced the heat-shock of this micro-infectious agent. But the power to regain and cope with the uncertainty has not been the same everywhere. To some extent, the developed nations have been able to tackle the bad days with their enriched resources, manpower and efficient system whereas this has become a total collapse for the developing and underdeveloped nations. Inefficiency and lack of social security have made life unbearable for the general people in these areas. What is the condition of the vaccination program? Whereas it is costly for the developed nations, it has simply become a dream for the developing nations. No one knows when the world will get a hundred per cent population with vaccination. In this paper we will cover these issues also we will take a look at the ravages of the pandemic in both worlds, as well as identifying the amalgamation of reasons behind the terrible second-wave in India and other developing nations.
\end{abstract}

Keywords: WHO, SARS CoV-2, lockdown, GDP, IMF, pandemic, asymmetric information, public goods, externality

\section{Introduction}

Since the initial discovery of the COVID-19 virus on December 2019 in Wuhan, China, the rapid and ravenous proliferation of the disease has resulted in a global pandemic that has stretched into the summer of 2021. As of $28^{\text {th }}$ May, 2021, the World Health Organization (WHO) has reported a total of 168 million confirmed cases and 3.5 million deaths worldwide (WHO, 2021). These numbers remain unprecedented, and the severe nature of the pandemic resulted in governments enforcing lockdowns and social distancing. In the medical front, countries around the world rushed to develop a proper vaccine in order to minimize the damage of the novel coronavirus.

Countries found themselves at a head, dealing with the massive number of cases, largely due to the contagious nature of the SARS-CoV-2 virus. Furthermore, there was a need to minimize possible further contamination too, which meant stricter social distancing and lockdown laws, which polarized the public due to their seemingly draconian nature. However, as the initial 2-week lockdown stretched to several months, that polarization turned to protests, as the economic instability of their nations took precedent over any pandemic. As the economic repercussions of widespread lockdown became apparent, governments all over the world tried to minimize the impact of the inevitable recession.

By the time the Phase 3 trials of the Pfizer-BioNTech vaccine had concluded on November $18^{\text {th }}, 2020$ (BioNTech-Pfizer, 2020), the world has gone through the ravages of the first wave, with the second wave imminent. However, at this stage, disparities in reactions to the pandemic had become apparent between first and third-world countries. As vaccination became more commonplace, this divergence only grew. As of $25^{\text {th }}$ May, 2021, a total of 1.54 billion vaccine doses have been administered all over the world (WHO, 2021).

As the world heads into its second year of the COVID-19 pandemic, these problems will come to define the global economy even more. 


\section{Objective of the Study}

This paper focuses on the disparity or differential treatment between developed and developing countries. Historically, it has been seen that first world countries always enjoy greater benefits in terms of income, consumption, services including medical facilities.

However, this pandemic situation has brought this fact to light and now people clearly know that not all the world's population is enjoying the same benefit. In this paper we will make clarification of these issues through review, analysis, and presentation of papers from renowned organizations, articles from scholars of the area as well as statistical data from secondary sources.

\section{Research Methodology}

This paper is a literature review of previously written papers in the same arena. During the coronavirus pandemic the number of papers on economic conditions, medical assistance, supply chain, and social security rose significantly. Our paper reviews both qualitative and quantitative data but, as the method suggests, no first-hand data have been collected or used in this analysis.

We reviewed papers in the areas of economics, finance, supply chain failure, and medical science that relate to the COVID-19 pandemic in particular. Twenty-one recently published articles from various journals (Journal of Public Economics, Economic Analysis and Policy, One Health, Applied Health Economics and Health Policy, etc.) were studied to better provide in-depth analysis of the issue at hand. Alongside these, articles from other credible sources (The New York Times, Eurostat, the IMF, WHO, etc.) were also researched for comprehensive understanding. This included region-wise data provided by national agencies and beyond, fact-checked to ensure credibility. The analysis presents a myriad of financial, economic, medical, and communication-related information and also critically focused on the disparity that exists and will show up in this corona pandemic situation.

\section{The Global Recession}

The global economy has seen a drastic fall in fortune following the pandemic. This has been true in all parts of the world.

The real GDP of the U.S. contracted by $4.8 \%$ (at seasonally adjusted annual rate/SAAR) within the first quarter of 2020 (Canuto, 2020), and a fall of 33\% during the second quarter (Reinicke, 2020). Furthermore, the level of unemployment was catastrophic, standing at $14.7 \%$ on April, 2020 (Canuto, 2020).

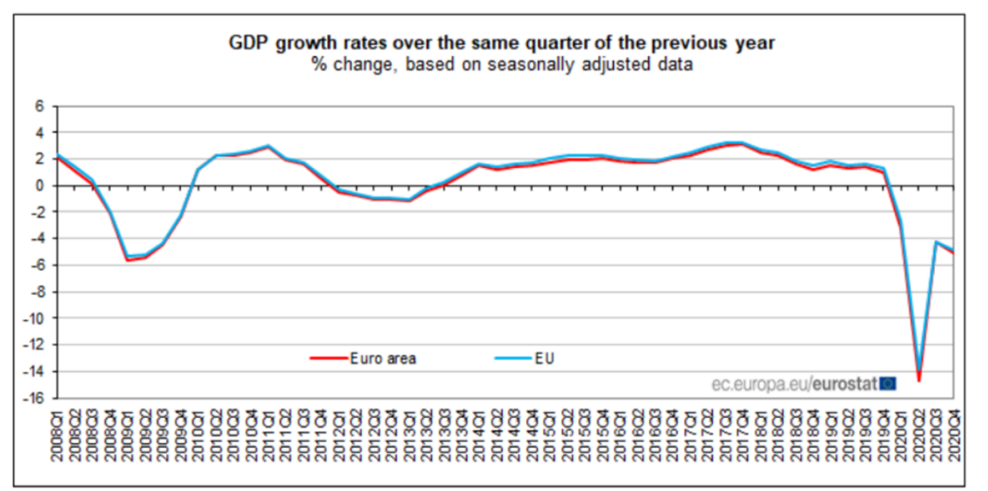

Figure 1. Eurostat, 2021. Preliminary flash estimate for the fourth quarter of 2020, s.1.: Eurostat.

The Eurozone also experienced drastic repercussions following the imposition of strict lockdown from mid-March 2020. In comparison to 2019, the GDP change for the Euro area fell by $14.7 \%$ during the second quarter of 2020 , and a further $5.1 \%$ by the fourth quarter (Eurostat, 2021). The unemployment rate also rose to $7.5 \%$ in November 2020 (Eurostat, 2020).

The Chinese economy shrunk for the first time in 50 years, with a $6.8 \%$ year-on-year, $10.0 \%$ quarter on quarter (The Straits Times, 2020). Unemployment there got as bad as 80 million Chinese being out of jobs in March, with the urban unemployment rate standing at $5.9 \%$. (Laura $\mathrm{He}, 2020$ ). 


\section{Effect of COVID-19 on China's Annual GDP Growth Rate}

10

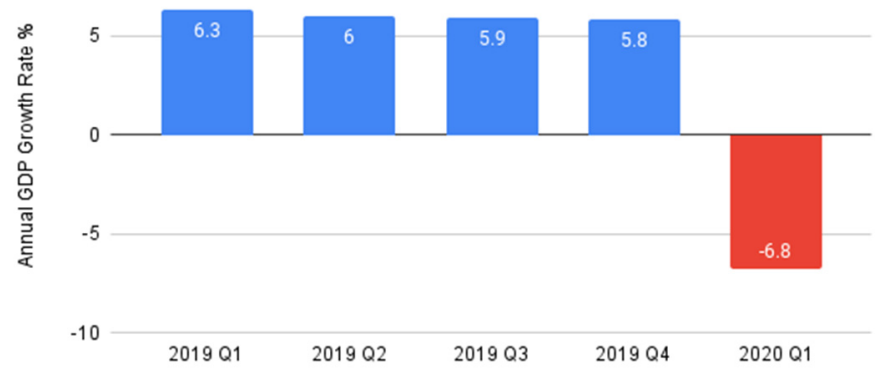

Figure 2. Fall in China's GDP. Data from National Bureau of Statistics of China

The developing world has also faced dire consequences.

India, with the second largest population in the world, suffered tremendously due to the pandemic, with 28.7 million recorded cases, and 344 thousand deaths (WHO, 2021). Despite initial estimations for FY21 placing its GDP growth highest amongst G-20 nations (India Today Web Desk, 2020), the first quarter of FY21 saw a 23.9\% contraction instead (The Times of India, 2020). The unemployment rate increased to $26 \%$ by $19^{\text {th }}$ April, 2020. By June, the rate had fallen back to usual rates. However, the devastating second-wave resulted in further unemployment, with the rate on June 6, 2021 sitting at 12.7\%, and showing signs of rising (Centre for Monitoring Indian Economy Pvt. Ltd., 2021).

India's neighbour, Bangladesh, suffered as well. While the GDP of Bangladesh actually rose during 2020, at a rate of $5.2 \%$, this is actually much lower than 2019's rate of $8.2 \%$. (Asian Development Bank, 2021). Lower rates of growth in a developing country such as Bangladesh can be far more harmful than in the developing world. Furthermore, the level of national poverty was predicted to go up my $25.13 \%$. Unemployment also rose by $13 \%$ (Enamul Hafiz Latifee, 2020).

In terms of the global economy, the IMF compared the decline the world economy to that of the financial crisis of 2008-9. While the global economy receded by $1.6 \%$ in 2009, the aftermath of the COVID-19 pandemic Figure would leave the world with a recession of $4.2 \%$, with most countries facing negative GDP growth rates. (IMF, 2020).

International trade suffered similarly, with the decrease in trade comparable to the 2008-9 financial crisis, as shown in the following illustration (UNCTAD, 2020).

Consumer and producer uncertainty in the market is also rampant, with volatility in stocks worldwide. Firms and governments share uncertainty regarding the growth of the economy as a whole, further lending into economic instability that has come to define the pandemic. (Dave Altig, 2020)

Overall, the global economy was hopelessly disrupted by the COVID-19 pandemic. While the whole world shared in the misery, it also highlighted the rising disparities between nations.

\subsection{Government Responses}

One primary source of large differences between the first and third world came in the form of the government responses to the pandemic. While both have suffered from less-than-ideal initial responses, the following lockdown and enforcement of restrictions have been night and day in both worlds.

In the United States, despite the backlash received by the Trump administration due to the admittedly slow response to rising cases, as soon as government intervention became commonplace by March-April 2020, the

positive effect of government spending in fighting the pandemic became apparent. Although initial estimations placed the possible death toll from COVID-19 in the US as high as 2.2 million (William Wan, 2020), strict lockdown restriction have kept the actual death toll below 600,000 (WHO, 2021). Regardless of this, the death toll in the USA is the highest among all nations struck by COVID-19, largely due to failures that we will cover later. 
Furthermore, the amount of funds available to the US government puts it at a clear advantage to less fortunate nations. Restrictions form only the first form of pandemic prevention, as keeping people away from social gatherings can be an increasingly uphill battle. Economic hardship continues to force people out, as the price of lockdown is steep. Incidentally, however, the US were able to keep millions of Americans satisfied, with larger amounts of business loans, financial assistance in need, and unemployment benefits. (Note 1).

It is natural that third-world countries would be unable to provide such massive amounts of infrastructural help, due to the monumental costs incurred, with the US alone putting an estimated US\$2.3 trillion into its 'CARES Act' (116th Congress, 2020). This is in stark contrast to a developing nation such as Bangladesh, whose total GDP equals US\$365 billion (Dhaka Tribune, 2021). To put it in perspective, the total GDP of Bangladesh is around $15.8 \%$ of the total estimated expenditure on the 'CARES Act'.

As a representative of developing nations' government responses, we will use Bangladesh. As of June 9, 2021, Bangladesh has had 815 thousand confirmed cases of COVID-19, and 12,913 deaths.

One large hurdle that has faced the country throughout the over 1 year of the pandemic has been sufficient levels of testing. Due to the comparatively low capacity of the medical centres in many of the country's viral epicentres, many people are being left undiagnosed, or are freely wandering despite being asymptomatic. As a result, Bangladesh's tests/million metric is one of the lowest in the Indian subcontinent, as shown in the table (Saifur Rahman Chowdhury, 2020).

Table 1. Comparison of COVID-19 cases in south Asian countries

\begin{tabular}{llllll}
\hline Country & Total cases & Total deaths & Total recovered & Total tests & Tests/1 million population \\
\hline India & 822603 & 22144 & 516206 & 11024491 & 7987 \\
Pakistan & 243599 & 5058 & 149092 & 1514858 & 6855 \\
Bangladesh & 178443 & 2275 & 86406 & 921272 & 5593 \\
Afghanistan & 34194 & 971 & 20882 & 78959 & 2027 \\
Nepal & 16649 & 35 & 8011 & 588353 & 20185 \\
Maldives & 2617 & 13 & 2238 & 59981 & 110923 \\
Sri Lanka & 2454 & 11 & 1980 & 114765 & 5359 \\
Bhutan & 80 & - & 55 & 26559 & 34424 \\
\hline
\end{tabular}

Abbreviation: COVID-19, coronavirus disease-19. Data from the dashboard of the Worldometer for COVID-19.

Restrictions are, while in place, not as thoroughly enforced. This has resulted in an escalation of the COVID situation, especially during the second and third waves.

It is easy to discredit the importance of proper government enforcement in the fight against the pandemic. However, as the graph below shows, research has shown that higher levels of government stringency can result in a genuine decrease in the number of cases (Viktor Stojkoski, 2020). Furthermore, the healthcare infrastructure available in a country was also a major determinant of capacity for a country to execute test and report when identifying the people with infection. (Viktor Stojkoski, 2020).

\subsection{Social Security}

Social security constituted a significant portion of the economic disparity that defined the pandemic period. During periods of such economic unrest and uncertainty, one of the primary objectives of the government is to provide some semblance of normalcy to the general public by advocating for policies that increase social security, thus reducing the negative impact on the households all around the economy. However, the ability of different governing bodies to provide these amenities varies greatly, and the overall impact is largely dependent on the extent of proper government initiative. By taking the United States and Bangladesh as representative of the economic climates in developed and developing countries, respectively, it is possible to quantify that disparity.

The US has been able to provide able support to its populace. Their social security was further ensured by the three stimulus checks that were issued by the Internal Revenue Service (IRS). The three checks issued were as follows (Government of the United States, 2021):

- $\$ 1,200$ in April 2020 
- $\$ 600$ in December 2020/January 2021

- $\$ 1,400$ in March 2021

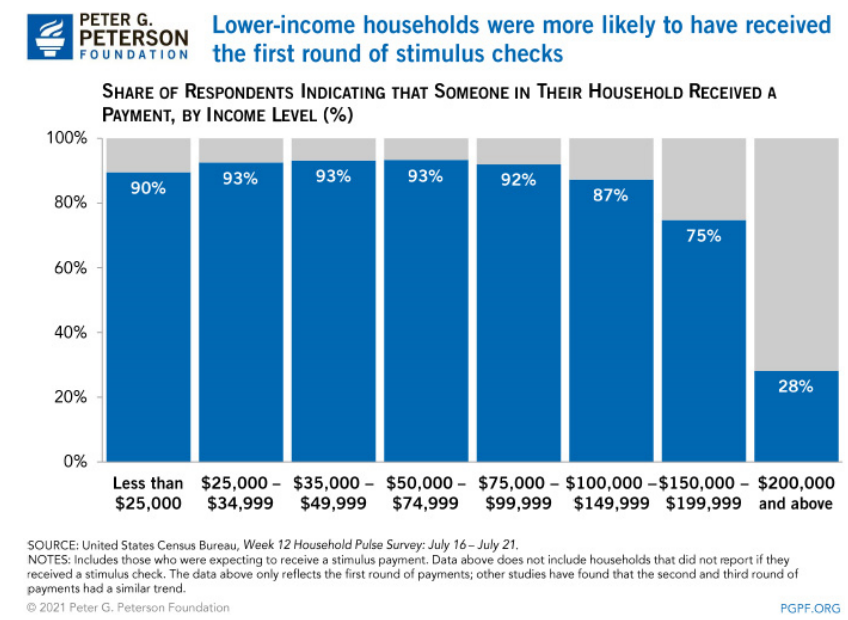

Figure 3. Distribution of stimulus checks within American households

The budgetary cost totalled around $\$ 867$ billion (Congressional Budget Office, 2021).

While primarily focused on economic engagement, the stimulus checks also served as a beacon of hope to the populace. Furthermore, due to their focus on helping lower-income household, economic disparity within the United States, which had risen during the pandemic, fell. This is shown in the diagram provided (Peter G. Peterson Foundation, 2021).

In stark contrast, however, developing countries such as Bangladesh were largely unable to provide such levels of social security support to their respective populations. While plans were initially made in order to provide social security packages to a large part of the general public, those plans were never properly implemented.

Research suggested that an adequate level of social protection intervention would require Tk.960 billion, but the actual stimulus packages provided by the government amounted Tk.60 billion. Not only was this amount inadequate, the ultimate purpose of this package, that of transferring income, was ultimately unsuccessful due to the inability to get the help to the low-income families that required it. Ultimately, instead of decreasing economic inequality, the package worsened an already bad situation (Ahmed, 2021). As we move along, the disparities between the developed and developing world in a post-COVID world will only grow.

\section{The Second (and Third) Wave}

\subsection{In Developed Nations}

The pandemic was not kind enough to leave in one wave, as it continued to harass the world's economies and countries through multiple waves. Both developed and developing nations suffered from multiple waves. However, due to the timing and nature of the initial waves, the second waves took place at vastly different times. The second wave in Europe- the area hit second after China- took place in March-April 2020. In contrast, the second wave in India took place at around the same time the following year. With this information in mind, along with how the world has changed in the one year in between, it is important to look at the major differences between the two areas and their responses to similar issues.

One defining factor of the second wave in Europe was the distinct lack of rising death rates, that usually accompanied rising new case numbers (Nick James, 2021). This can be attributed to many reasons, not the least of them being the far more symmetric information available to the general public, as well as much more efficient public policy enforcement by the governments of various nations. The US saw a similar result in their second wave.

The third wave of COVID-19 in the US, however, was a different story, as it saw a massive rise in new cases, comparable to the level of cases in India in March-April 2021 (see 'In Developing Nations'). The same low mortality issue was here, and it must bring up questions regarding the level of economic agency of the government over the life of the general public and to what extent it should be held responsible for such a large gap between these two worlds. 


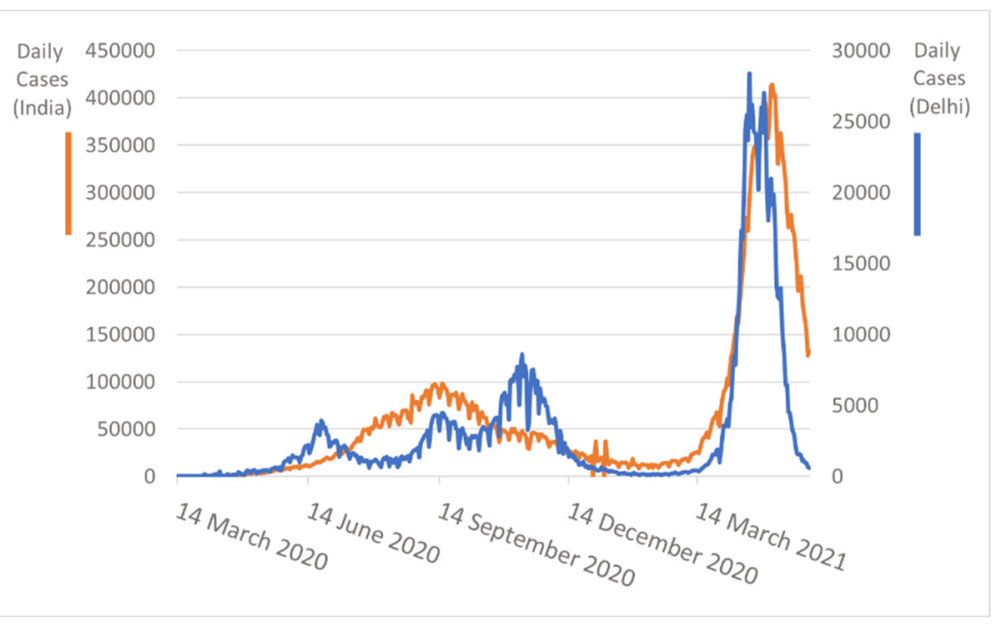

Figure 4. COVID-19 cases in India and Delhi

Source. https://ourworldindata.org/coronavirus/country/india

\subsection{In Developing Nations}

The second and third wave have hit developing countries incredibly hard.

The first country to feel the brunt of this was India, who, almost overnight, saw a massive influx of new cases, and more alarmingly, higher death rates. This was a result of mutations in the SARS-CoV-2 virus, which created far more potent variants of the already dangerous disease. Eventually, WHO classified the two variants as 'Delta' and 'Kappa' (The Quint, 2021). This second wave of infections devastated the country, as it saw a record average of 300,000 new cases per day, as well as 2,000 deaths (Jeffrey Gettleman, 2021). Delhi, the capital of India, was worse hit by this, as this upsurge of cases saw it suffer an alarming fourth wave.

In addition to this, the issues were further catalysed by an utter failure in providing the necessary vaccines, as a shortage became more apparent. This can be attributed to a logistics network failure (mentioned later in the 'Broken Supply Chain' subsection).

However, this fate was not limited to only India, neighbouring countries, and other developing countries soon followed suit, showing a scary precedent for the socio-economic factors at the heart of the COVID-19 pandemic.

Laos and Nepal both faced shortages in medical equipment. Hospitals in Thailand are facing immense pressure due to the new strain of COVID-19 that constituted 98\% of the cases documented there (Jinshan Hong Randy Thanthong-Knight, 2021). Slowly, as different developing countries become centres of more worry, the danger of the economic disparity between first and third world countries is all too obvious, as are the repercussions of maintaining the status quo.

As experts continue to term the pandemic situation in low-income nations as "very serious" (Jinshan Hong Randy Thanthong-Knight, 2021), the global community continues to snub it. This is largely due to the large disconnect between the situation in developed nations and developing nations, and it's absolutely imperative that the same level of expertise, care, and funding be put into helping the people of less developed nations, if true economic equity is to be maintained on the geopolitical scale.

\section{The Cost of a Cure}

With the creation of the COVID-19 vaccine, the world was thrown into a frenzy of vaccinating its populations in order to return to pre-pandemic situations, thus starting to eliminate the economic issues caused by lockdown. Due to the immediate and sensitive nature of the countries are going to be providing the vaccine for free to all taxpayers. Despite the private cost to consumers being zero, the costs of the vaccine go far beyond that. 


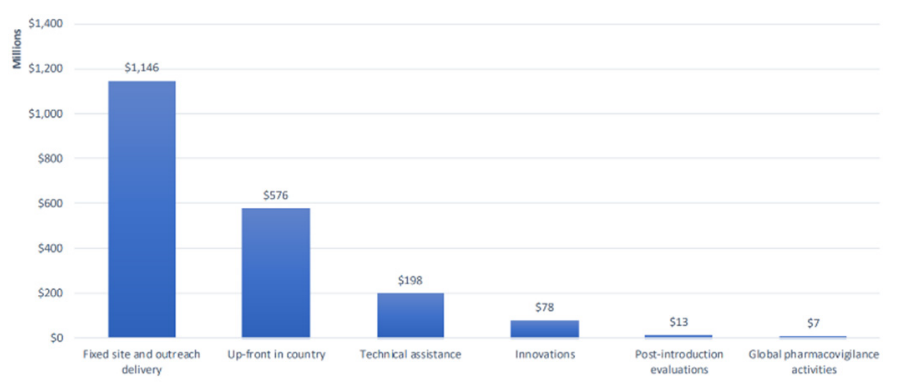

Figure 5. Costs of COVID-19 vaccine delivery in 92 AMC economies during 2021 (WHO, Gavi, UNICEF, 2021)

As the US was the first country to develop a vaccine, it had an upper hand in vaccinations. With a total of 301 thousand vaccine doses administered, the US is at the forefront of world vaccination. In the same vein, much of the western world has been vaccinating their populations, with the total doses per 100 people around $60-100$ (WHO, 2021).

However, this is in stark contrast to vaccinations in the developing world, with the per 100 statistics at dismal levels (from nearly 0 to a maximum of 17 in India). It is important to understand that a large portion of this disparity is due to the massive cost of the vaccine itself, as well as the failures of the supply chain in providing ample vaccination doses to third-world country, as evidenced by the shortages in India, Nepal, and Laos.

Provisions have been made to provide proper vaccinations to the 92 Advance Market Commitment (AMC) countries. The financial cost of the entire operation totals around US $\$ 2.018$ billion. Of this entire cost, only $15 \%$ amounted to technical assistance on the global and regional arena, with $57 \%$ of it being on outreach (in-country) and delivery on fixed site. The rest $28 \%$ is made up of up-front costs incurred by the countries, this includes installation and training (WHO, Gavi, UNICEF, 2021).

Despite these provisions being made for developing countries, the total number of people that are expected to be reached by this initiative is still only 546.3 million people during 2021 . This accounts for $8.5 \%$ of the population of India and $17 \%$ of the other AMC countries, including Bangladesh (WHO, Gavi, UNICEF, 2021), still woefully behind developed countries.

As we can see, the state of the global vaccination drive provides evidence of the reality of the economic disparity that is separating developed and developing countries. In order to commence global economic healing and stability post-pandemic, it is important that such differences be met up with necessary initiatives.

\section{A Catastrophic Failure}

\subsection{Market and Government Failure}

The COVID-19 pandemic was able to show the faults that lie at the very center of the current capitalist economic system. A large proportion of the issues highlighted can be attributed to the simple inability of the market to account for the massive changes caused by the pandemic and subsequent lockdowns, resulting in socially inefficient allocation of resources, decreasing social welfare. In most countries, the government's inadequacy also resulted in further harm to the populace they promised to protect. The reasons behind these failures are (Dana, 2020):

1. Asymmetric information (covered in the 'Age of Misinformation' subsection)

2. Negative Externalities. A primary example can be the negative impact on the market due to the lockdown. Although essential, the restrictions put by the government on movement and transport significantly hampered the level of economic activity. Not only was cashflow limited, a liquidity crisis also affected private suppliers (Williams, 2020). This resulted in businesses incurring severe losses, which resulted the laying off of staff members and rising unemployment. As each problem fed into the next, a vicious cycle of problems is created.

3. Public Goods (or the lack thereof). As governments all over the world tried their best to cope with the pandemic, there were a lot of fundamentals that were left on the wayside. A primary example is education. While virtual education has become more and more popular, the efficiency of that education has continued to be low, especially in low-income countries such as Bangladesh. This severely impacts the future viability of the economy of already struggling countries. 
4. Uncertainty. The market was not able to make proper adjustments due to the unpredictable nature of pandemic. As a result of this, economic agents have been unable to make any headway, and this unpredictability has been apparent in the stock market, where the volatility was comparable to the 2008-9 financial crisis (Dave Altig, 2020).

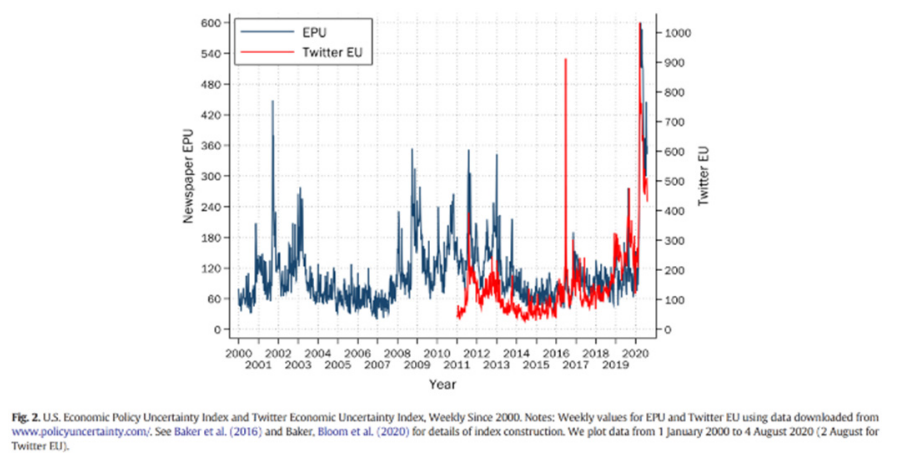

Figure 6. VIX, implied stock returns volatility, Weekly Since 2000 (Dave Altig, 2020)

\subsection{Broken Supply Chains}

One of the major reasons behind the failures of the global economy in dealing with COVID-19 was the catastrophic failure of the worldwide healthcare supply chain. Not only was the globalized system of trade entirely ineffective in dealing with the geopolitical stress the pandemic put on the world, it also resulted in further disparity developing between first and third world countries.

The inflexible manner of the global supply chain has resulted in an unfair skewing of essential medical equipment towards more well-off nations, regardless of how much less fortunate countries may require them. The graph shown above (Devon E. McMahon, 2020) illustrates this problem well, as the sample of low-income countries can be seen having severe shortages in their supply of important medical equipment.

However, even developed nations have suffered the blow of a global supply chain collapse. Even the USA was unable to provide adequate levels of masks to the populace (Financial Times, 2020).

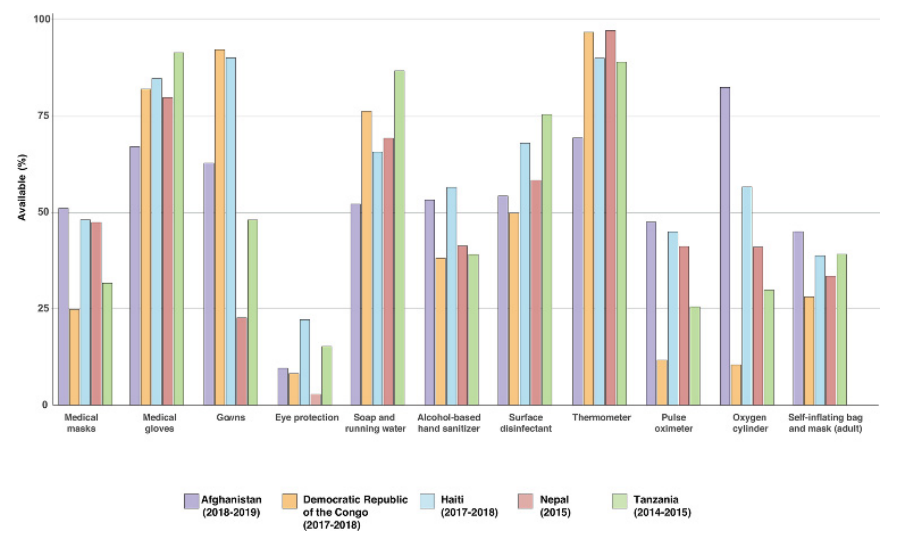

Figure 7. Availability of medical equipment in low-income countries (Devon E. McMahon, 2020)

\subsection{Age of Misinformation}

Information failure played a crucial role in the larger failure of the market and governments to deal with the issues presented by the COVID-19. Progress in all medical departments was heavily marred by the spread of baseless conspiracy theories and false information (Jon Agley, 2021)

Some primary examples of misinformation spread during the pandemic include: 
1. Masks, and other similar prevention method, are ineffective in stopping the spread of the SARS-CoV-2 virus. This misconception began with the tweet of the U.S. Surgeon General Jerome Adams. He later changed his position on the matter, but the damage had already been done (Allassan, 2020).

2. Alcohol will be able to protect against COVID-19. Not only was this rumor entirely false, it catalyzed problems in many countries, especially lower income countries. For example, Iran reported a large amount of methanol poisoning among its people, which can be attributed to the false information people had heard about the alleged protective properties of alcohol (Trew, 2020).

3. $5 \mathrm{G}$ towers will propagate the virus. Despite the fact that wireless technology has no relation with virus contagion, false reports of this supposed relation began to be taken seriously all over the world, especially the United Kingdom. This translated into action as over seventy $5 \mathrm{G}$ cell towers were burned in Europe and Canada (Reichert, 2020).

4. Bill Gates is using the COVID-19 vaccine to embed microchips in people. This conspiracy theory was born due to Bill Gates' comments on a possible pandemic pre-COVID-19, as well as his large donations to vaccination research (Daisuke Wakabayashi, 2020). Not only did the US Federal Bureau of Investigation get involved, a large amount of the population still rejects the vaccine due to the rumor.

These are only some of the hundreds of falsehoods that have gained traction during the pandemic. The incredibly harmful nature of misinformation in the era of the COVID-19 pandemic cannot be overstated. While the direct consequences are already horrible, the indirect effects are unlikely to be fully known until far later, when it will be too late to make any meaningful change. It is important that the market, as well as the government, does more to ensure fairness in information and awareness, instead of fuelling tensions in an already volatile situation.

\section{Conclusion}

\subsection{Main Results}

All in all, the COVID-19 pandemic was effective in creating a display of the worst parts of the global economy. By dismantling the world's infrastructure nearly overnight, it was able to show the massive flaws in the systems we all trust. Not only was it able to shed light on the fragile state of the global economy, it also highlighted the truth about economic disparity, and how the current world order is skewed towards preserving the status quo. This distinct inequality is not only apparent, but disappointing in general human terms.

\subsection{Contribution to Literature}

This paper endeavours to bring together scholarly knowledge regarding the economic, medical, global supply chain and social security issues brought to light by the COVID-19 pandemic. Through this accumulation of articles and papers, an issue of dramatic inequality is brought forth more clearly. This paper serves as a building block for more in-depth research based on the individual facets of the economy, as highlighted above.

\subsection{Study Limitations}

The paper is limited in scope due to its nature as a literature review, generally. As a result of this, no first-hand data had been collected. Thus, the limitations of each individual article and paper are applicable to this paper as well.

\subsection{Future Research Directions}

As stated above, this paper can act as the basis of future work in regards to such inequality, focusing on topics such as the supply chain failure or social security issues, all of which can contribute to the overall literature on the topic, which is currently lacking.

\subsection{Final Thoughts}

It is imperative that we all learn the lessons the coronavirus has taught us regarding the economy, and take steps to make sure that such a dramatic collapse will never be repeated. Enhancing our understanding of such an issue can not only help in disaster management in future circumstances, but can help tackle these issues of inequality in the near future. 


\section{References}

116th Congress. (2020, March 19). CARES Act. Retrieved June 2021, from https://www.congress.gov/116/bills/s3548/BILLS-116s3548is.pdf

Ahmed, S. (2021). Covid-19 and social protection in Bangladesh. Retrieved June 2021, from https://www.thefinancialexpress.com.bd/views/covid-19-and-social-protection-in-bangladesh-1612103677

Allassan, F. (2020). Surgeon general defends reversal on face mask policy. Retrieved 2021, from https://www.axios.com/surgeon-general-reversal-face-mask-d385e2d5-42b7-433e-89a6-3584f3e61bf3.html

Asian Development Bank. (2021). Economic indicators for Bangladesh. Retrieved June 6, 2021, from https://www.adb.org/countries/bangladesh/economy

BioNTech-Pfizer. (2020, December 2). Update on our COVID-19 vaccine development program with BNT162b2. BioNTech-Pfizer. Retrieved from BioNTech- Investors \& Media: https://investors.biontech.de/static-files/53f0968a-279b-4f82-a2fc-d67dcb6e4e91

Canuto, O. (2020). The Impact of Coronavirus on the Global Economy. Policy Center for the New South.

Centre for Monitoring Indian Economy Pvt. Ltd. (2021). CMIE STATISTICS. Retrieved June 6, 2021, from https://www.cmie.com/kommon/bin/sr.php?kall=warticle \&dt=2020-04-21\%2010:40:01\&msec $=873$

Congressional Budget Office. (2021). Congressional Budget Office.

Daisuke Wakabayashi, D. A. (2020). Bill Gates, at Odds With Trump on Virus, Becomes a Right-Wing Target. Retrieved 2021, from https://www.nytimes.com/2020/04/17/technology/bill-gates-virus-conspiracy-theories.html

Dana, J. (2020). Why Markets Fail? The Economics of Covid-19. Northeastern University, from https://cssh.northeastern.edu/pandemic-teaching-initiative/why-markets-fail-the-economics-of-covid-19/

Dave Altig, S. B. (2020). Economic uncertainty before and during the COVID-19 pandemic. Journal of Public Economics. https://doi.org/10.3386/w27418

Devon E. McMahon, G. A. (2020). Global resource shortages during COVID-19: Bad news for low-income countries. PLOS Neglected Tropical Diseases. https://doi.org/10.1371/journal.pntd.0008412

Dhaka Tribune. (2021). Bangladesh's per capita income rises to \$2,227. Retrieved June 2021, from https://www.dhakatribune.com/business/2021/05/17/planning-minister-bangladesh-s-per-capita-income-incr eased-to-2-227

Enamul Hafiz Latifee, M. S. (2020). Corona crisis can be a best opportunity to start own business. Retrieved June 6, 2021, from https://www.observerbd.com/news.php?id=269275

Eurostat. (2020). Euro area unemployment at 8.3\%. Eurostat., from https://ec.europa.eu/eurostat/documents/portlet_file_entry/2995521/3-01022021-AP-EN.pdf/db860f10-65e3 -a1a6-e526-9d4db80904b9

Eurostat. (2021). Preliminary flash estimate for the fourth quarter of 2020 . Eurostat, from https://ec.europa.eu/eurostat/documents/portlet_file_entry/2995521/2-02022021-AP-EN.pdf/0e84de9c-0462 -6868-df3e-dbacaad9f49f

Financial Times. (2020). My pity package of Chinese face masks sends a bigger message. Retrieved 2021, from https://www.ft.com/content/556a4bea-8e76-11ea-a8ec-961a33ba80aa

Government of the United States. (2021). Economic Impact Payments - Stimulus Checks. Retrieved 2021, from https://www.usa.gov/covid-stimulus-checks

IMF. (2020). World Economic Outlook, April 2020: The Great Lockdown, International Monetary Fund, from https://www.imf.org/en/Publications/WEO/Issues/2020/04/14/weo-april-2020

India Today Web Desk. (2020). IMF projection for India's GDP growth highest in G-20, says RBI Governor $\begin{array}{lllll}\text { Shaktikanta Das. } & \text { Retrieved } & \text { April } & \text { 17, } & \text { 2020, }\end{array}$ https://www.indiatoday.in/business/story/rbi-governor-shaktikanta-das-indian-economy-covid19-imf-project ion-gdp-growth-1667889-2020-04-17

National Bureau of Statistics of China. (2020). Quarterly Data. Retrieved November, 2020, from http://www.stats.gov.cn/english/ 
Jeffrey Gettleman, S. Y. (2021). As Covid-19 Devastates India, Deaths Go Undercounted. Retrieved 2021, from https:/www.nytimes.com/2021/04/24/world/asia/india-coronavirus-deaths.html

Jinshan Hong Randy Thanthong-Knight, J. S. (2021). After sweeping India, fierce Covid-19 waves hit other developing nations. Retrieved 2021, from https://www.business-standard.com/article/international/it-s-not-just-india-fierce-covid-19-waves-hit-otherdeveloping-nations-121050400368_1.html

Jon Agley, Y. X. (2021). Misinformation about COVID-19: evidence for differential latent profiles and a strong association with trust in science. BMC Public Health. https://doi.org/10.21203/rs.3.rs-35919/v2

Laura He, N. G. (2020). 80 million Chinese may already be out of work. 9 million more will soon be competing for jobs, too. Retrieved May $\quad$ 8, 2020, from https://edition.cnn.com/2020/05/08/economy/china-unemployment-intl-hnk/index.html

Nick James, M. M. (2021). COVID-19 second wave mortality in Europe and the United States. Chaos: An Interdisciplinary Journal of Nonlinear Science, 31(3). https://doi.org/10.1063/5.0041569

Peter G. Peterson Foundation. (2021). HOW DID AMERICANS SPEND THEIR STIMULUS CHECKS AND HOW DID IT AFFECT THE ECONOMY? Retrieved June 2021, from https://www.pgpf.org/blog/2021/05/how-did-americans-spend-their-stimulus-checks-and-how-did-it-affect-t he-economy

Reichert, C. (2020). 5G coronavirus conspiracy theory leads to 77 mobile towers burned in UK, report says. Retrieved 2021, from https://www.cnet.com/health/5g-coronavirus-conspiracy-theory-sees-77-mobile-towers-burned-report-says/

Reinicke, C. (2020). US GDP plunged by a record 33\% annual rate in the 2 nd quarter as coronavirus $\begin{array}{llllll}\text { lockdowns } \quad \text { raged. } & \text { Retrieved } & \text { July } & \text { from }\end{array}$ https://www.businessinsider.com/us-q2-gdp-record-decline-coronavirus-pandemic-recession-lockdowns-eco nomy-2020-7?r=US\&IR=T

Saifur Rahman Chowdhury, T. C. (2020). Response to COVID-19 in Bangladesh: Strategies to Resist the Growing Trend of COVID-19 in a Less Restricted Situation. Asia Pacific Journal of Public Health, 32(8). https://doi.org/10.1177/1010539520951689

The Quint. (2021). COVID Variants Found in India to Be Labelled 'Delta', 'Kappa': WHO. Retrieved 2021, from

https://www.thequint.com/coronavirus/covid-variants-found-in-india-to-be-labelled-delta-and-kappa-who\#re ad-more

The Straits Times. (2020). China's Q1 economy shrinks 6.8\%, first contraction in decades. Retrieved April 18 , 2020, from https://www.straitstimes.com/business/economy/chinas-q1-economy-shrinks-68-first-contraction-in-decades

The Times of India. (2020). GDP collapses 23.9\% in Q1, worst among big economies. Retrieved September 1 , 2020 , from https://timesofindia.indiatimes.com/business/india-business/gdp-collapses-23-9-in-q1-worst-among-big-eco nomies/articleshow/77860877.cms

Trew, B. (2020). Coronavirus: Hundreds dead in Iran from drinking methanol amid fake reports it cures disease. Retrieved 2021, from https://www.independent.co.uk/news/world/middle-east/iran-coronavirus-methanol-drink-cure-deaths-fake-a 9429956.html

UNCTAD. (2020). Key Statistics and Trends in International Trade 2020. United Nations, from https://unctad.org/system/files/official-document/ditctab2020d4_en.pdf

Viktor Stojkoski, Z. U. (2020). The socio-economic determinants of the coronavirus disease (COVID-19) pandemic. https://doi.org/10.1101/2020.04.15.20066068

WHO. (2021). WHO Coronavirus (COVID-19) Dashboard|WHO Coronavirus (COVID-19) Dashboard With Vaccination Data. Retrieved from WHO Coronavirus (COVID-19) Dashboard | WHO Coronavirus (COVID-19) Dashboard With Vaccination Data: https:/covid19.who.int/ 
WHO, Gavi, UNICEF. (2021). Costs of delivering COVID-19 vaccine in 92 AMC countries. WHO, Gavi, UNICEF,

https://www.who.int/publications/m/item/costs-of-delivering-covid-19-vaccine-in-92-amc-countries

William Wan, J. D. (2020). Experts and Trump's advisers doubt White House's 240,000 coronavirus deaths estimate. $\quad$ Retrieved June $7, \quad$ from https://www.washingtonpost.com/health/2020/04/02/experts-trumps-advisers-doubt-white-houses-240000-c oronavirus-deaths-estimate/

Williams, O. D. (2020). COVID-19 and Private Health: Market and Governance Failure. Development, 63. https://doi.org/10.1057/s41301-020-00273-x

\section{Note}

Note 1. https://www.usa.gov/covid-small-business-loans

\section{Copyrights}

Copyright for this article is retained by the author(s), with first publication rights granted to the journal.

This is an open-access article distributed under the terms and conditions of the Creative Commons Attribution license (http://creativecommons.org/licenses/by/4.0/). 